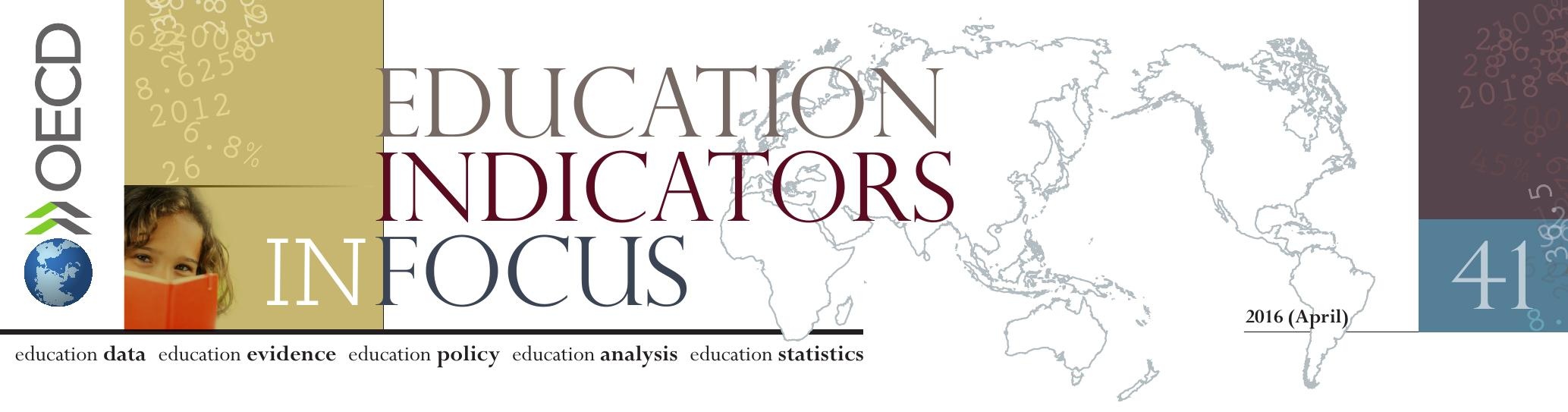

\title{
How much do tertiary students pay and what public support do they receive?
}

- OECD countries differ significantly in the way spending on tertiary education is shared between public and private sources of funding, and in the financial support they provide to students.

- Countries with high tuition fees tend to also be those where private entities other than households make a more significant contribution to funding tertiary institutions. By contrast, in countries with more progressive tax regimes, students often pay low or no tuition fees and have access to generous public subsidies for tertiary education, but then face high income tax rates.

- An increasing number of OECD countries charge higher tuition fees for international students than for national students, and many also differentiate tuition fees by field of education, largely because of the divergent returns on wages.

- In countries with high tuition fees, student financial support systems that offer all students loans with income-contingent repayments combined with means-tested grants can be an effective way to promote access and equity while sharing the costs of tertiary education between taxpayers and students.

OECD countries differ in the way spending on tertiary education is shared between public and private sources of funding.

Most countries recognise the importance of tertiary education and have similar goals for it, such as strengthening the knowledge economy, widening access for students, boosting completion rates and ensuring the increasing demand for tertiary education while at least maintaining the financial sustainability of their tertiary education systems. However, OECD countries significantly differ not just in their level of expenditure per tertiary student but also in the way the spending is shared among governments, students and their families, and other private entities such as private businesses and non-profit organisations.

The financing patterns that have emerged at tertiary level differ from those in primary and secondary education. First of all, the use of private resources is much more common. Private funding represents $30 \%$ of total spending on average, and more than half in Australia, Chile, Japan, Korea, the United States and OECD partner country Colombia (Figure 1).

In most countries, individual households account for most of the private expenditure on tertiary education. However, countries with high tuition fees tend to be those where other private entities, such as private businesses and non-profit organisations, also contribute more to funding tertiary institutions. Thus, the share of expenditure on tertiary institutions covered by private entities other than households reaches 15\% or more in Australia, Israel and the United States, and exceeds $20 \%$ in Canada, Korea and the United Kingdom, six countries where tuition fees are higher than the OECD average.

The average tuition fees charged by tertiary educational institutions differ widely across OECD countries.

There are large differences between countries in the average tuition fees national students pay for bachelor's degree or equivalent programmes. For example, in the four Nordic countries with available data (Denmark, Finland, Norway and Sweden), and in Estonia, the Slovak Republic, Slovenia and Turkey, public institutions do not charge tuition fees for full-time national students but individuals face high income tax rates in most of these countries. By contrast, tuition fees for public institutions are higher than USD 2000 (converted using purchasing power parities, PPPs) in less than half of the countries with available data (Figure 2). 

institutions (2012)

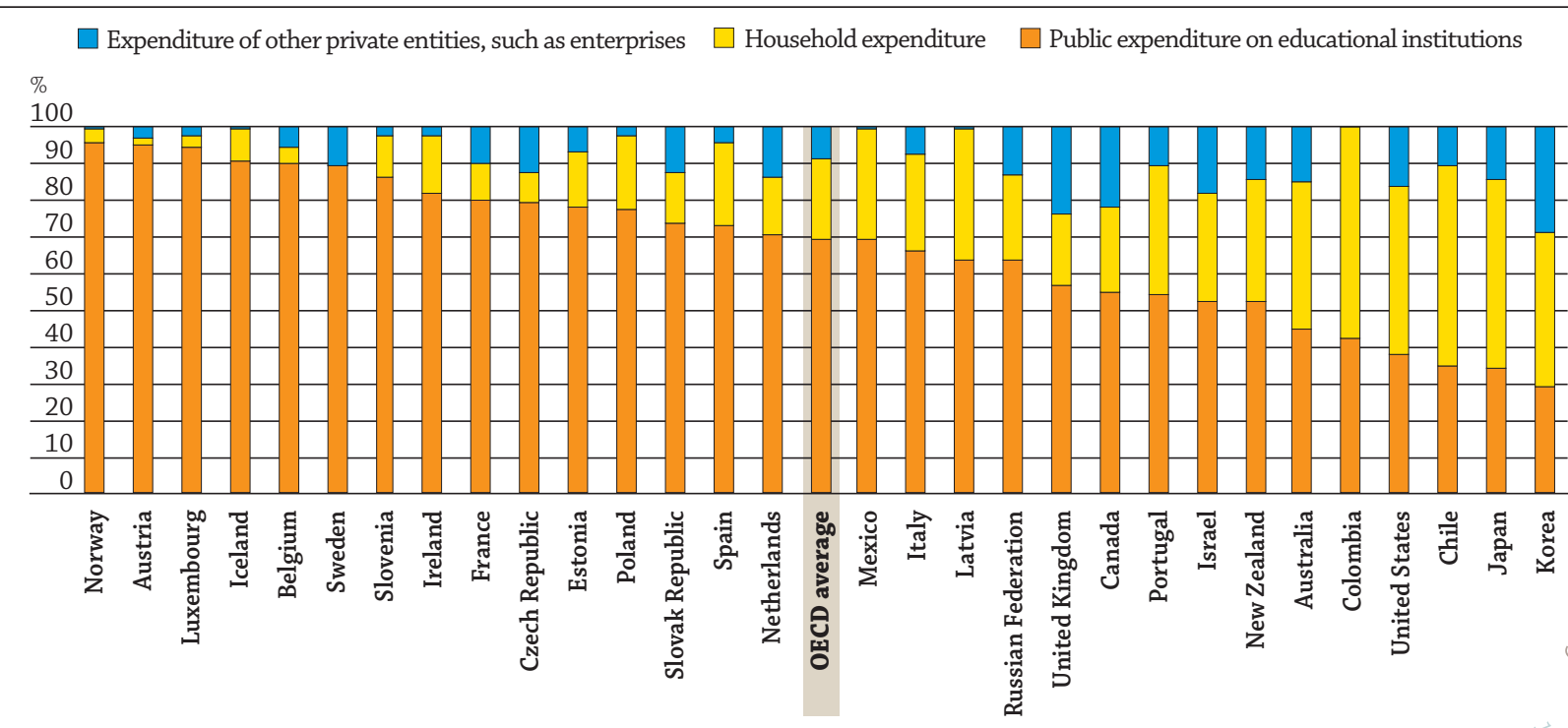

Countries are ranked in descending order of the proportion of public expenditure on tertiary educational institutions.

Source: OECD (2015), Education at a Glance 2015: OECD Indicators, OECD Publishing, Paris, http://dx.doi.org/10.1787/eag-2015-en, Table B3.1.

In all OECD countries, people with a master's or equivalent degree have better employment opportunities and earn more than those with only a bachelor's degree. However, the tuition fees charged by public institutions for national students in master's or equivalent programmes are generally not much higher than those charged for bachelor's programmes. In two-thirds of OECD countries, public institutions charge similar tuition fees to fulltime national students regardless of the level of the programme. In the rest, the difference in tuition fees between bachelor's and master's programmes is substantial. For example, tuition fees for master's programmes in public institutions are 30\% higher than those for bachelor's programmes in Korea and the United States, 60\% higher in Australia and more than three times higher in Belgium (French Community) and Colombia (Figure 2).

An increasing number of OECD countries charge international students higher tuition fees than national students, and many also differentiate tuition fees by field of education.

As countries try to strike the right balance between keeping student charges at a level guaranteeing equity in access to tertiary education, and finding sufficient funding for their tertiary education systems, they increasingly look to other measures. For example, some countries with highly subsidised tertiary education systems, such as Denmark and Sweden, increased tuition fees for non-European Union students in recent years, joining a long list of countries that charge higher rates for international students.

In the same vein, where tertiary institutions charge tuition fees for students, half of the ten OECD member and partner countries with available data - Australia, Canada, Colombia, New Zealand and the United States - have different fees for different fields of study, whether reflecting the costs of operating the programme, or the divergent returns on wages they provide. Thus, in Hungary and New Zealand the higher the cost of operating the programme, the higher the level of tuition fees educational institutions charge. The differentiation can also be linked to the salaries that graduates in certain disciplines can expect to receive. In Australia for example, the highest fees for master's programmes are nearly three times the lowest - from USD 10231 in social sciences, business and law to USD 3876 in education. Australia has even attempted to link the level of fees to labour-market opportunities by lowering tuition fees for fields with skills shortages, in order to attract more students.

\section{Tuition-fee structures and systems of student support vary widely across OECD countries.}

OECD countries differ dramatically in how the cost of tertiary education is structured and also in the financial support they provide to students. For example, in countries with more progressive tax regimes, such as Denmark, Finland, Iceland, Norway and Sweden, students pay low or no tuition fees and have access to generous public subsidies for 
Figure 2. Average annual tuition fees charged by public and private institutions at bachelor's, master's or equivalent levels (2013/14)

Tuition fees charged to full-time national students, converted into USD using PPP for GDP

Converted in USD using PPPs
1. Tuition fees refer to independent-private institutions as the majority of students are enrolled in these institutions.
2. Tuition fees range from USD 215 to USD 715 for university programmes.
3. Tertiary educational institutions do not charge tuition fees in these countries.
Countries are ranked in descending order of the average annual tuition fees charged by public institutions at bachelor's or equivalent level.
Source: OECD (2015), Education at a Glance 2015: OECD Indicators, OECD Publishing, Paris, http://dx.doi.org/10.1787/eag-2015-en, Table B5.1.

tertiary education, but face high income tax rates. In contrast, tuition fees can be much higher in Australia, Canada, New Zealand, the United Kingdom and the United States, although students in these countries also have access to significant financial support. Before reforms in Japan and in Korea, students paid comparatively high tuition fees, but had relatively low access to public subsidies. Meanwhile, in Austria, Belgium, France, Italy and Switzerland, students pay little or nothing for tertiary education, but have limited access to financial aid.

In many countries, a well-developed student financial support system is vital to ensuring equity and widening access to tertiary education.

Data from Education at a Glance 2015 suggest that charging high level of tuition fees compared to the OECD average, while simultaneously giving students opportunities to benefit from comprehensive financial aid systems, can be an effective way for countries to increase access to tertiary education, make efficient use of limited public funds, and acknowledge the significant private returns that students receive from tertiary education. Thus, it is worth noting that countries with particularly well-developed financial aid systems - such as Australia and New Zealand - all have aboveaverage tertiary entry rates compared to other OECD countries, despite having very high tuition fees. To be sure, this approach has its limits: if the cost of tertiary education is perceived as too expensive, individuals may choose not to pursue it, even if public subsidies to support them are available.

What is more, the high entry rates among some countries that charge no tuition fees may be due as much to their highly developed student financial support systems to cover living expenses, as to the absence of tuition fees. For instance, in Finland and Norway - two countries with above-average tertiary entry rates - more than $50 \%$ of students benefit from public grants, public loans or a combination of both. By contrast, countries with no tuition fees but less-developed student aid systems - such as Austria and Italy - have lower entry rates (see Figure 3 and Indicator C3 in Education at a Glance 2015).

In countries with high tuition fees, the types of student aid that countries provide may be even more important.

At the same time, the existence of a robust financial support system may not be enough to assure good outcomes for tertiary education students; the type of aid is also critical. Here again, approaches vary across OECD countries. Student financial support systems that provide both loans with income-contingent repayments and means-tested grants not only promote access and equity at the front end of tertiary education, but also lead to better outcomes for students at the 
back end. Australia and New Zealand can be considered good examples of this model and have used this approach to mitigate the impact of high tuition fees, encourage disadvantaged students to enter tertiary education, and reduce the risks of high student loan indebtedness. Other OECD countries that offer means-tested grants and income-contingent loan repayments include Chile, Hungary, the Netherlands, New Zealand, the United Kingdom and the United States although in some of these countries, income-contingent repayments are initiated at the borrower's request.

\section{Figure 3. Distribution of scholarships/grants and public loans to students at bachelor's or equivalent level $(2013 / 14)$}

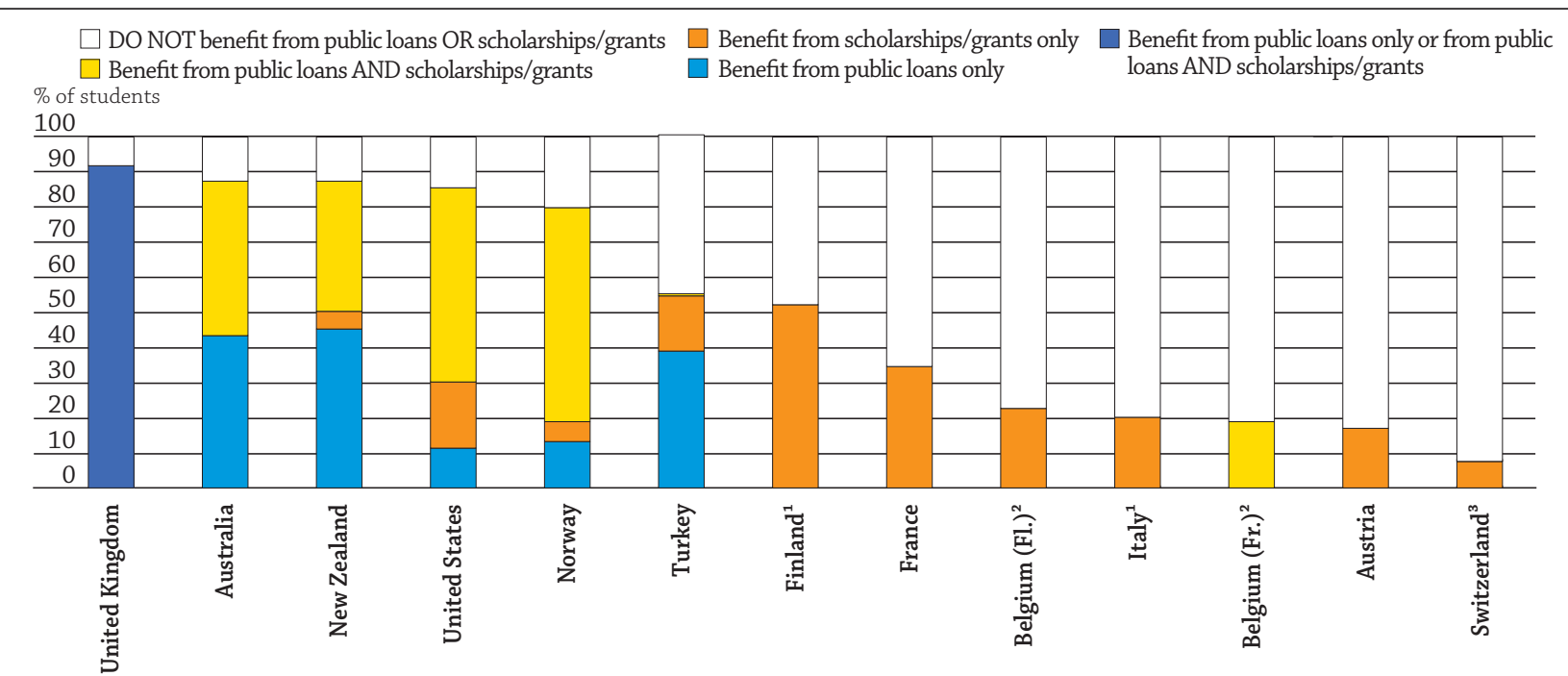

1. Includes master, doctorate or equivalent levels.

2. Includes master or equivalent level.

3. Bachelor's or equivalent level includes short-cycle tertiary programmes.

Countries are ranked in descending order of the percentage of students receiving financial support for their studies.

Source: OECD (2015), Education at a Glance 2015: OECD Indicators, OECD Publishing, Paris, http://dx.doi.org/10.1787/eag-2015-en, Table B5.3.

The bottom line: OECD countries differ significantly in the way spending on tertiary education is shared between public and private sources of funding, and in the financial support they provide to students. Striking the right balance between providing sufficient support to institutions and maintaining access and equity is challenging. In countries with more progressive tax regimes, students tend to pay low or no tuition fees and often have access to generous public subsidies for tertiary education, but in turn face high income tax rates. In countries with high tuition fees, student financial support systems combining meanstested grants with loans with income-contingent repayments can be an efficient way of promoting access and equity while sharing the costs of tertiary education between taxpayers and students.

\section{For more information}

OECD (2015), Education at a Glance 2015: OECD Indicators, OECD Publishing, Paris, http://dx.doi.org/10.1787/eag-2015-en.

OECD (2008), Tertiary Education for the Knowledge Society: Volume 1 and Volume 2, OECD Publishing, Paris, http://dx.doi.org/10.1787/9789264046535-en.

\section{Contact}

Eric Charbonnier (eric.charbonnier@oecd.org)

\section{Visit}

www.oecd.org/education/education-at-a-glance-19991487.htm

Education Indicators in Focus (previous issues)

PISA in Focus

Teaching in Focus

\section{Next topic}

How do early childhood education systems differ around the world?

Photo credit: @ Ghislain \& Marie David de Lossy/Cultura/Getty Images

This paper is published under the responsibility of the Secretary-General of the OECD. The opinions expressed and arguments employed herein do not necessarily reflect the official views of OECD member countries.

This document and any map included herein are without prejudice to the status of or sovereignty over any territory, to the delimitation of international frontiers and boundaries and to the name of any territory, city or area.

The statistical data for Israel are supplied by and under the responsibility of the relevant Israeli authorities. The use of such data by the OECD is without prejudice to the status of the 